\title{
Iowans in the Arts: Ruth Suckow in the Twenties
}

\author{
Margaret Matlack Kiesel
}

IN THE EARLY YEARS of the 1920s Ruth Suckow flashed upon the American literary scene like a streak of lightning in a midwestern August sky. These were the years when she was "discovered" by Henry L. Mencken, and quickly won national recognition as a writer of short stories and novels in the school of realism. In the 1970s her fiction attracted a new generation of readers, with an accompanying interest in her life. She was not only a talented writer but she was a young woman who represented in many ways the "new woman" of the 1920 s who believed in each individual's right to independence and freedom to choose his or her own way.

In a recent series, "Rediscovered Fiction by American Women," Arno Press reprinted in 1977 two of Ruth Suckow's early books-her first novel, Country People (first published by Alfred A. Knopf in 1924), and a collection of her early short stories under the title of Iowa Interiors (published by Knopf in 1926). In 1978 she was named to the Iowa Women's Hall of Fame by the Iowa Commission on the Status of Women for her contribution to the lives of Iowa women in her books and in her life.

Critical studies of Ruth Suckow's fiction have appeared during the past decade. In 1969 Leedice McAnelly Kissane's study, Ruth Suckow, was published by the Twayne Series of United 
States authors. In 1972 Ruth Suckow: A Critical Study of Her Fiction, by Margaret Stewart Omrcanin, appeared. Doctoral dissertations by Barbara Anne White and Sister Sara McAlpin are evidence of continued scholarly interest in Suckow's fiction. ${ }^{1}$

This revival of attention to Ruth Suckow's works prompts another look at her phenomenal success in the 1920s. When the decade began she was a young writer, whose talents were not yet acclaimed, living in Earlville, Iowa; when it ended she was living in Greenwich Village, had gained a national readership, and was recognized by New York critics and publishers.

Invariably, biographical accounts describe her as the daughter of a Congregational minister who was "discovered" by H. L. Mencken when he was editor of the avant-garde New York magazine, The Smart Set. While both statements are true, each is an over-simplification. In the first place, neither Ruth Suckow nor her father, William J. Suckow, fit the stereotypes of "minister's daughter" nor "Congregational minister." She was "discovered" by Mencken, but only because her own talent and style, as well as subject, fit exactly into his theory of what realistic fiction in post-World War I America should be. As he himself declared:

I am credited with discovering many writers who actually discovered themselves. Among those I whooped for in their earliest days are James Joyce, Ruth Suckow, James Stevens, Eugene

${ }^{1}$ Barbara Anne White, "Growing Up Female, Adolescent Girlhood in American Literature" (Ph.D. diss., University of Wisconsin, 1974); Sister Sara McAlpin, B.V.M., "Enlightening the Commonplace: The Work of Sarah Orne Jewett, Willa Cather and Ruth Suckow (Ph.D. diss., University of Pennsylvania, 1971). Editor's Note: The Suckow holdings at The University of Iowa Libraries consist of correspondence, 1918-1960, copies of manuscript notebooks, and clippings. In addition there are correspondence, notebooks, photos, and other materials relating to The Bonney Family (1928) and The John Wood Case (1959), and corrected drafts of articles and short stories. The latter collection is described in Frank Paluka, "Ruth Suckow: A Calendar of Letters," Books at Iowa, no. 1 (October 1964): 31-40 and no. 2 (April 1965): 31-40. The following is a list of depositories with scattered Suckow holdings: Huntington Library; Stanford Library; Beinecke Library; Knox College Archives; Notre Dame; Lilly Library; Houghton Library; University of Michigan; State University of New York, Buffalo; Columbia; Princeton; Ohio State; University of Pennsylvania; Randolph-Macon Woman's College; and the University of Vermont. 


\section{Ruth Suckow}

O'Neill and Dreiser. . . . But what I did for all these, and the rest likewise, was really very little. I was looking for good copy, not for orphans to rescue. ${ }^{2}$

Mencken was also looking for authors who were not of Anglo-Saxon stock. In one of the first letters he wrote to Ruth Suckow in August, 1921, he stated that her ancestry was similar to his own and that he believed that "Anglo-Saxon stock in America is played out" with the best literary output coming from those of "later immigration."

Mencken had spotted her Suckow name-but in jumping to the conclusion that her German name and four German grandparents meant that she was a pure ethnic he was over-simplifying. For, as a matter of fact, Ruth Suckow grew up between two cultures, both common to Iowa at the turn of the century. Predominant in her childhood and even into her early adult years was what she called "colonialism," by which she meant the strong New England culture which dominated the Congregational church with its Puritan roots, the public schools, and the college she attended, Grinnell. The second culture, that of her four German immigrant grandparents was alien to her until the time of the First World War and America's entrance into it in 1917:

The war was the first thing to make me realize that I actually came of German ancestry. Nearly every Summer [sic] of my childhood we had visited the farm where one grandmother and grandfather sat in rockers side by side, and the little Iowa town where the other grandmother and grandfather lived in a frame house painted in red and white to make it look as if it had been built of brick. But the ways of these old people were so different from any I had ever known that I had no real sense of belonging to them. There was nothing German in our home except noodle

${ }^{2}$ H. L. Mencken to Jim Tully, May 4, 1927, Guy J. Forbes, ed., Letters of H. L. Mencken (New York: Alfred A. Knopf, 1961). Permission to quote from letters granted by Alfred A. Knopf, Inc.

${ }^{3}$ Mencken to Ruth Suckow, August 16, 1921, Ruth Suckow Papers, Special Collections, The University of Iowa Libraries, Iowa City. Hereafter records from The University of Iowa Libraries are indicated by the symbol UIL. Letters from Mencken to Suckow are quoted with permission of Mercantile-Safe Deposit \& Trust Company, Baltimore, Maryland, Trustee under the Will of Henry L. Mencken. 


\section{The Annals of Iowa}

soup, a tree and frosted cookies at Christmas, and brown-covered copies of Die Gartenlaube. Our parents spoke German only when Christmas and birthdays were at hand or when my mother, calling some queer old customer by a still queerer name, laughed, and said "Don't ask me to translate that." We girls learned our German in school. ${ }^{4}$

But Mencken can be forgiven for focusing on Suckow's ethnicity. By 1921, when she began writing her serious short stories and the novel Country People, she had discovered her German roots. Each culture contributed to her development as a writer, and the strands of each are interwoven into her early fiction until it is as difficult to separate them as it is to separate the warp from the weft in a piece of weaving. In her own life, the warp might be said to be her German ancestry, the weft her environment-her immediate family and cultural interests.

R UTH SUCKOW WAS BORN on August 6, 1892 in Hawarden, Iowa. Her father had come to Hawarden in 1889 as minister of the Congregational church in this town which had been founded only a few years earlier. Mr. Suckow remembered the church as one that was "young and had worn no ruts, developed no hampering traditions . . . it was more like one big family."

Ruth Suckow remembered Hawarden as an idyllic place:

Almost by accident, by a kind of fortunate chance, I breathed in my very first hours that New World air which even then had passed away from much of the American continent. . . . I have found something of my town in Lincoln's New Salem, and in the early Springfield; in Edgar Lee Master's Spoon River Anthology; ... in New Litchfield, Connecticut, during the childhood of Harriet Beecher Stowe. ${ }^{6}$

In her novel New Hope (1942) she idealized the fictional town of New Hope and a minister's family. The fictional town parallels her birthplace and the fictional family her own family, espe-

"Ruth Suckow, "My German Grandfather," The American Mercury, vol. 12, no. 47 (November 1927): 280.

${ }^{5}$ W. J. Suckow, "Seventy Years in Retrospect: An Autobiography," (Unpublished Manuscript, n.d., Suckow Papers, UIL), 125.

${ }^{6}$ Ruth Suckow, "A Memoir," Some Others and Myself (New York: Rinehart and Company, Inc., 1952), 197-198. 


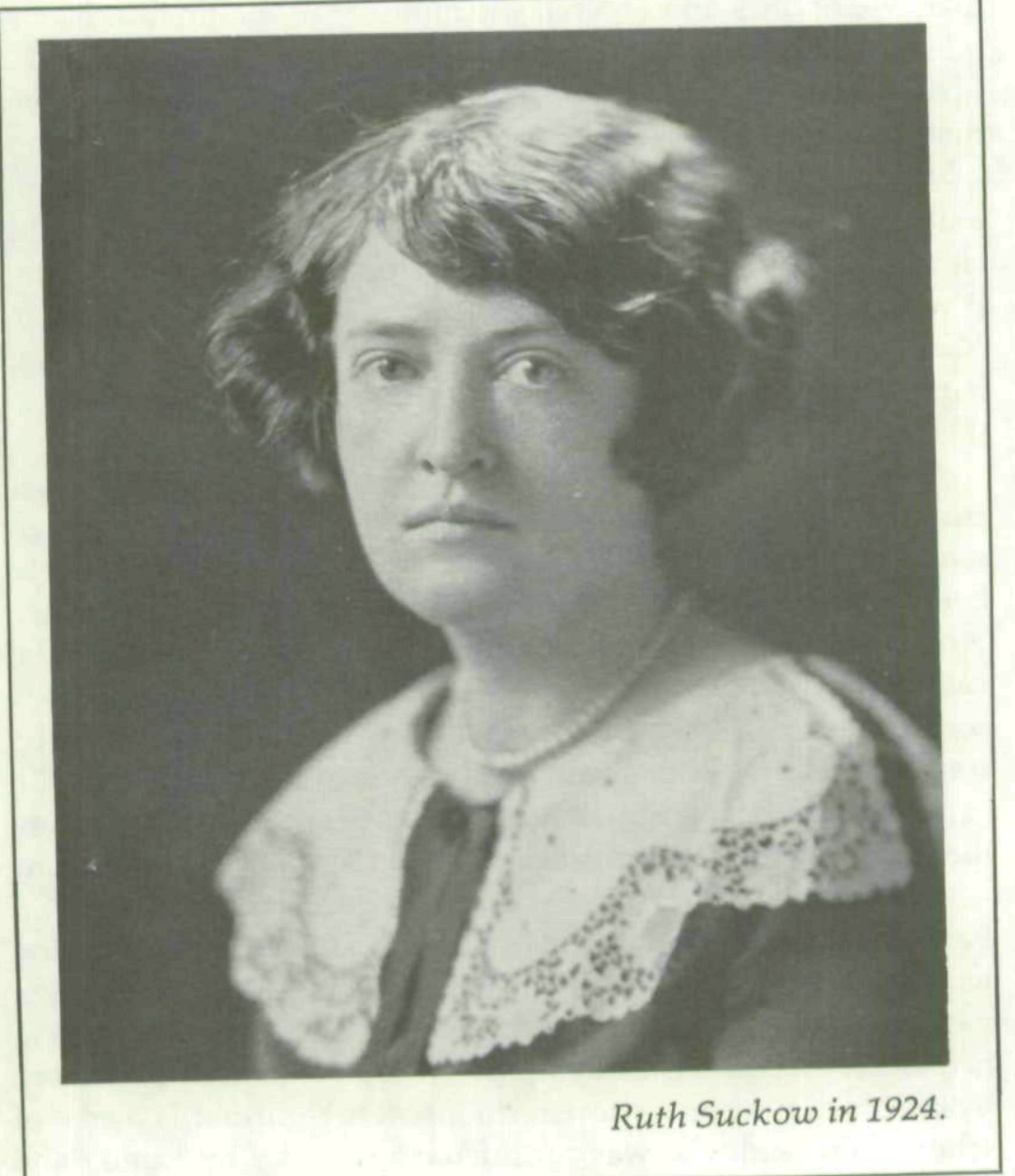

cially her father in the figure of the minister. Her autobiographical "A Memoir," contains a delightful account of Hawarden, although she called it simply "H----.".

His Hawarden church was Mr. Suckow's first as a minister in the Congregational denomination. He grew up in the German Methodist church which was the center for a small band of German pietists who had come to Iowa to live on farms in Hancock County, in German Township, situated near Garner. He had little formal education, but did manage to attend a seminary in Galena, Illinois for a short time. He decided to leave the Ger- 


\section{The Annals of Iowa}

man Methodists and entered the ministry in the English Methodist denomination, with his first assignment in Sioux Rapids, Iowa, where he married Anna Mary Kluckhohn and where their first daughter, Emma was born.

Not finding the Methodist hierarchy and church polity to his liking, he accepted the opportunity to fill the pulpit of the Hawarden Congregational Church when it was offered to him. It was a good church for this young minister from a German Methodist background simply because it was new and not hampered by a strict New England tradition, as were many of the early Congregational churches in Iowa.

Anna Kluckhohn's background was both similar and different from her husband's. Her parents, like his, had come from Germany to America to seek a new life. Her parents, like his, had been converted to Methodism by the evangelist, Peter Cartwright. Anna's father was a minister, who came from an educated family in Germany; her mother came from a well-to-do social class. William Suckow's father was a shoemaker by trade; his mother was uneducated although a woman of intelligence and strong piety. Both the Suckow and Kluckhohn families had come to farm in Iowa to seek a more healthful climate -the Suckows from New York State; the Kluckhohns from St. Paul, Minnesota, where Anna's father had been a minister and where she was born and had grown up. Young William Suckow met his future wife when he went over to the Kluckhohn farm to help her father with the haying. He was undoubtedly impressed by the older minister, whose sermons were regarded as pieces of scholarship, and who was considered a saint by his family and friends. He must also have been impressed by the attractive daughter whom he courted and married and who became Ruth Suckow's mother:

My mother had been a pretty girl-more than pretty, lovely. She was courted by many. My aunt used to tell me about the young man who walked twenty miles in tight new shoes to call upon my mother! She had lived in a city before her family came out to the prairie community; and she had attended college for a time, and teacher's institutes. She must have been a superior young lady in a country settlement. What had been her real expectations when she had chosen, from among her suitors, the 


\section{Ruth Suckow}

green young man just off the farm in the near-by rural township, whose parents spoke Low German while her parents spoke High German ${ }^{7}$

Mr. Suckow's ministry in Hawarden was by and large successful, and he and his wife enjoyed the social life in the small community. They belonged to a "novel club" in which fifteen couples representing "fifteen prominent families" took turns writing chapters for a novel. Bicycling had just come into fashion, and the young minister used his bicycle not only for recreation but also for business, riding it around the countryside when he went out to call on his country parishioners. The new game of croquet was much in vogue, and in his autobiography he told of making his own set out of vulcanized rubber balls with mallets made from rolling pins, and "arches" of wire. ${ }^{8}$

With Ruth's birth the family was complete. She and Emma, six years older and already in school when Ruth was a baby, were close friends from the beginning, Emma rejoicing at the birth of a baby sister. The happiness of the Suckow family was marred, however, when Mrs. Suckow was stricken with a thyroid condition from which she suffered for the remainder of her life.

The Suckows were in Hawarden until 1898, with the exception of two years when Mr. Suckow was minister of the LeMars Congregational Church and Mrs. Suckow sought various health cures. In 1898, when Ruth was six years old, he became minister of the Algona Congregational Church. He found the Algona church very different from the one in Hawarden, which had had ministers, like himself, who were "raised up in Iowa."

The Algona church was founded in 1856 by the Reverend Chauncey Taylor, who came out to the new land of Iowa from the Green Mountains of Vermont as a missionary-preacher, following in the footsteps of so many New England Congregational ministers who had begun establishing churches in Iowa as early as 1838 . There is irony in the fact that "Father" Taylor, as he and other of the early patriarchs were called, disdained the Congregational churches of eastern Iowa as being "too estab-

"Suckow, "A Memoir," 220.

${ }^{8}$ W. J. Suckow, "Seventy Years in Retrospect," 130-131. 
lished," and regarded the Fort Dodge Congregational Church (1856) as "too ancient."

Algona, where the town was just being laid out, suited Father Taylor; he established his church and was minister there until 1873. But something had happened to his pioneer church, at least his successor twenty-five years later found it "very stiffnecked New England." What Mr. Suckow found most displeasing was the old custom of renting pews to families by the year. This was highly undemocratic, he felt, since the first choice of pews invariably went to the largest financial contributors. Mr. Suckow persuaded his congregation to give up this custom. He also objected to a church "Society" which he regarded as a remnant from "Colonial days." 10

His daughter Ruth, on the other hand, who started school in Algona, found the New England "colonial" influence in the church and in school much to her liking:

As a child, I had no doubt that our denomination was naturally superior to all others. A youthful American patriot, and a very fiery one, I was proud that our church was the Church of the Pilgrims. It seemed to me the most historic denomination. The Pilgrim children, whom we living children had learned to know in school, in our readers, and in our Thanksgiving Day programs, were Congregationalists ... Congregationalists first set foot on Plymouth Rock. When our family took a vacation trip East (I was then about seven) Emma and I looked upon Plymouth Rock with a sense of proud possession. ${ }^{11}$

In the towns she lived in as a child it was the old ladies of New England origin, members of the Congregational churches, whom she admired most and whose houses she liked to visit. One of these women was her special favorite-an "intellectual of an older period," who told her stories of the early woman's suffrage meetings, and of herself being called "Violets from Iowa" by Elizabeth Cady Stanton. When Ruth Suckow later lived in New England at various times, she found that:

${ }^{9}$ Truman O. Douglas, The Pilgrims of Iowa (Boston: The Pilgrim Press, 1911), 122-127, passim.

${ }^{10}$ W. J. Suckow, "Seventy Years in Retrospect," 145.

${ }^{11}$ Suckow, "A Memoir," 192. 


\section{Ruth Suckow}

The houses there seemed as familiar to me as if I had just stepped out and returned; they were like the houses of those older members of the midwestern Congregational church. . . . To be sure, our own blood ancestors had not landed on this stern and workbound coast. Our name was an oddity among the historic Congregational names of New England origin-the Willards, Woods and Taylors. Nevertheless I had the feeling of kinship with the Pilgrim band, even though I was far from being a Mayflower descendant. I seemed, in a way, better acquainted with Priscilla and John Alden than with some of the people I saw every day. ${ }^{12}$

When she wrote The Odyssey of a Nice Girl many years later, which is strongly autobiographical, she described the conflict in family origins of her heroine, Marjorie Schoessel, whose father was of German descent while her mother was a native American and eligible to belong to the D.A.R. Marjorie's grandparents Blossom "were esteemed citizens, leading members of the Congregational church." When Marjorie's family went on summer visits to the farm of her German Schoessel grandparents, she was "ashamed that Grandma and Grandpa Schoessel were German, and lived in the country, and spoke broken English." When the family went to the country German Methodist church on Sunday she "disapproved of the congregation-the solemn brown-faced farmers holding their hats on their knees, the fat women holding babies and wearing such countrified hats." She thought of her own church at home where the ladies walked down the aisle "in summer dresses and silk gloves, children with big hair ribbons." ${ }^{13}$ There may well have been such conflicts between the young Ruth Suckow's environment at home, with its genteel tradition of New England predominant, and the earthier qualities of life on the farm of her Suckow grandparents.

Both of her parents, although without much formal education, were bright and articulate. The parsonage was filled with books; reading aloud was a favorite family pastime. Both the Bible and the novels of Charles Dickens became familiar to Ruth from family reading. She and Emma were allowed to read

${ }^{12}$ Ibid., 192, 194.

${ }^{13}$ Ruth Suckow, The Odyssey of a Nice Girl (New York: Alfred A. Knopf, Inc., 1925), 12-26, passim. 


\section{The Annals of Iowa}

nearly everything they wanted to; there were not the pious constraints one might have expected in a minister's family of the time. The parents gave their daughters every encouragement as their talents developed in ways in which their father and mother were also interested. Mrs. Suckow was regarded as "artistic" while Mr. Suckow "loved the arts, so far as he knew themwent in for considerable writing outside his sermons, and even for a little musical composition." Emma "had, and exercised, a profusion of talents." By the time she was seven Ruth "sat down to begin a child's novel in one of my father's little notebooks to be illustrated by the author."14

Her father attributed both of his daughters' interest in writing to their mother:

I think that a considerable share of the literary talent of both my girls should go to their mother, who possessed fine native literary ability, although she never had much chance to exercise it. She came of literary ancestry. Her father, though he wrote no books, preached sermons of much literary finish. ${ }^{15}$

In this he was perhaps overly modest, because Ruth appreciated her father's literary talents and the influence his efforts had on her. Nearly all her first writing was done in her father's study, using his discarded notebooks for her own compositions:

Nearly all my early stories were written in these beautiful small notebooks, the first pages of which might be given over to sermon titles, or to the material of church organizations, with notations in my father's small, clear, cramped yet emphatic, careful printing. I loved to sit in this room with its peaceful yet somehow intense atmosphere, a row of paper dolls on the floor in front of me ... the kind of activity that even then I liked best of all others-literary composition going on in the scarcely broken stillness. ${ }^{16}$

Mr. Suckow's own sermons were carefully and thoughtfully written; he liked to write poetry and he published one book of poems. After his daughter became famous, a poem of his appeared in the Des Moines Register, with the notation by the distinguished Harvey Ingham that Mr. Suckow had been "for

${ }^{14}$ Suckow, "A Memoir," 235.

${ }^{15}$ W. J. Suckow, "Seventy Years in Retrospect," 199.

${ }^{16}$ Suckow, "A Memoir," 198. 
more than forty years ... one of the outstanding Congregational ministers in Iowa, occupying a number of important pulpits, preaching many sermons that have attracted statewide attention."17

And then, waiting in the wings, so to speak, was her Grandfather Suckow, who was a great teller of tales, but whose talent she did not recognize until she was a grown woman and beginning to write her own stories. As a child she used to sit under an apple tree on the farm to listen to his German folk songs, and his tales of crossing the Atlantic in a sailing ship, but her recollection of this was that it was "to keep her out of mischief" while her mother was busy. ${ }^{18}$

As the family moved on from Algona to Fort Dodge, and then to Manchester in 1906, she continued to grow up in much the same environment as she had known in Algona. In Manchester she entered high school and became a member of her first "crowd." It was a wrench to leave in 1907 when her father took a position as field secretary for Grinnell College. Emma was a student at Grinnell College, graduating in 1908. Ruth graduated from Grinnell High School in 1910 and entered Grinnell College as a freshman that fall. ${ }^{19}$

Grinnell was founded by New Englanders, and there was a strong Congregational influence both in the town and college. The college was in the classical liberal arts tradition with idealistic religious overtones. When President J. H. T. Main addressed her freshman class, he proclaimed: "You are not inmates of an institution, you are part of it; and a very important part at that." She later wrote a long short story with the title "A Part of the Institution," published by Mencken in The Smart Set, which is a satirical account of her student days at Grinnell and which was regarded by the college administration as disloyal and sharply critical of her alma mater. ${ }^{20}$

${ }^{17}$ Harvey Ingham, "Father-Daughter-Two Notable Iowans," The Des Moines Register, undated clipping in author's possession.

${ }^{18}$ Suckow, "A Memoir," 207; "My German Grandfather," 280.

${ }^{19}$ Suckow, "A Memoir," 229.

${ }^{20}$ Grinnell College Scarlet and Black, vol. 28, no. 2 (September 17, 1910). For a fuller account of her years at Grinnell, and the influence of her sister 
Suckow left Grinnell at the end of her junior year to enter the Curry School of Expression in Boston. This was chiefly due to her strong desire to emulate Emma, who had been a star in college plays. But there might have also been her disillusionment with what she called the "milky watery idealism" of the small denominational college. In an article for College Humor about Grinnell College, she pointed out that, "Everywhere the New England atmosphere was visible, but translated into Middle Western terms," and that the college was of an "ethical cast which tends to crowd out the aesthetic." She majored in English literature and shunned the "more earnest theme-a-day writing classes." 21

Before leaving for Boston, Ruth and her roommate spent the summer in Yellowstone Park, working in a resort. Although not an unknown thing for college students to do, it was adventurous. She was a student at the Curry School for two years, receiving a diploma in 1915. She left an account of her experiences there in her novel, The Odyssey of a Nice Girl, where the same Marjorie Schoessel, who had disdained her German farm grandparents, gloried in all the cultural advantages of Boston. Like her fictional Marjorie, Ruth Suckow returned to Iowa a changed young woman, only to find that Iowa had not changed.

Her father had left Grinnell College by this time and, after a ministry at Edwards Church in Davenport, had once more become minister of the Congregational church in Manchester. Emma, now married and with two children, was living in Denver but had become ill with tuberculosis. While Mrs. Suckow went out to Denver to help with Emma's household, Ruth kept house for her father in Manchester. It was an unhappy experience for her because she was immediately thrust into the position of the unmarried daughter of the minister, although she was only twenty-three years old. She opened a studio and offered to teach "Voice and Body Training, Story Telling, Reading and Public Speaking," but this venture was not a success.

Emma, see Margaret Matlack Kiesel, "Ruth Suckow's Grinnell," The Grinnell Magazine, November-December 1975.

${ }^{21}$ Ruth Suckow, "Grinnell," College Humor, May 1930, 97-101, passim. 


\section{Ruth Suckow}

She changed places with her mother, moving out to Denver to stay with Emma, and enrolled in the University of Denver to finish her college degree in English literature. She received her bachelor of arts degree in 1917, and master of arts in 1918. While doing graduate work she was an assistant in the English department, teaching some English classes. Of this experience she said later, "I had a chance to teach English in the University of Denver and took it. I did that a year. It was just about long enough. I didn't want to teach. I wanted to write. . . . I began with poetry-very bad poetry." 22

What was probably her first work to be published in a national magazine was the poem, "Orchard House," which appeared in the popular weekly, The Youth's Companion of January 15, 1918. The poem is about the house Louisa May Alcott and her family lived in in Concord, Massachusetts-undoubtedly Ruth had visited it while in Boston. Two more poems appeared that year, one in Touchstone and one in The Midland. In her book on Ruth Suckow, Leedice McAnelly Kissane quotes from a letter which Ruth and a close friend, Amy Buchanan, wrote in March 1918 from Denver to Harriet Monroe, editor of Poetry: A Magazine of Verse. They asked Miss Monroe whether it was possible to teach and write; how an unaccepted writer could earn a living; whether unknown writers could succeed unless they lived in Chicago or New York. They also submitted some poems, but these were not accepted, although three years later three poems by Ruth Suckow appeared in Poetry. ${ }^{23}$

The questions which the two aspiring poets asked Monroe suggest the dilemma facing Ruth Suckow in 1918. She was now twenty-six years old, her apprenticeship was over, and she must support herself. She and Amy worked one summer as waitresses in Estes Park, and she worked for a while with a firm which made automobile road maps, but these were stopgaps.

Then she heard of a woman, Delia Weston, who lived near Denver and raised bees, selling enough honey during six months

${ }^{22}$ Suckow, "A Memoir," 229; Marion L. Starkey, "Ruth Suckow from Iowa to New York," Boston Evening Transcript, May 24, 1930.

${ }^{23}$ Leedice McAnelly Kissane, Ruth Suckow (New York: Twayne Publishers, Inc., 1969), 22. 


\section{The Annals of Iowa}

of the year to support herself the other six months. Although her friends "hooted" at her, Ruth Suckow bought a share of the woman's bees and set herself to learning the beekeeping business. Amy Buchanan described the enterprise:

To most girls of her age this would have been an intolerable sacrifice to make for her ambition. She couldn't spend her money on pleasures, it must be hoarded. She worked in khaki trousers and shirt with a hideous bee hat and veil, and small as she [was] she lifted heavy bee frames and worked long hours at the honey press. ${ }^{24}$

In the summer of 1919 while her mother and father were in Colorado for a vacation in the mountains, her mother died suddenly - not of the thyroid condition which had plagued her for so long but of a heart condition. Ruth returned to Iowa with her father, and in the early months of 1920 she settled with him in Earlville, Iowa, where he had taken the position of minister of the Congregational church. She was accepted into the little community "with remarkable kindness and leniency, because I was a queer kind of minister's daughter, no two ways about itone who did not teach a Sunday School class nor attend the Christian Endeavor." 25

Earlville furnished her an ideal place for setting up her beekeeping business. Her father helped her in the enterprise, and together they bought sixty hives of bees and set up their "Orchard Apiary" on a flower farm on the northern outskirts of Earlville. For six years her bee-keeping business flourished. After her father remarried and moved away from Earlville she took as partner a neighbor, Laura Werkmeister, and the two women sold honey all the way from Earlville to Dubuque, making deliveries in a Model-T Ford. In his account of her years in Earlville, Ferner Nuhn, whom she married in 1929, wrote that there was "much in Earlville that appealed to Ruth. She loved the changing seasons, the nearby woods, the rolling farm lands. ... Ruth enjoyed, too, the life of this rural town, which was another of the small Iowa communities she had known since childhood." But it was also a sad time for Ruth Suckow-two

\footnotetext{
${ }^{24}$ Amy Buchanan, "Personal History of Ruth Suckow," The Des Moines Register, January 1934.

${ }^{25}$ Suckow, "A Memoir," 231.
} 


\section{Ruth Suckow}

more deaths in the family followed her mother's death by only a few years. First came the death in 1920 of Emma's little son and in 1923 Emma herself died in a sanatorium in Colorado-her death hastened, in her father's view, by grief over the loss of her son. Since Mr. Suckow had remarried and had a new wife and two stepsons, Ruth was left quite alone, with only her niece, Emma's daughter, left in the close-knit immediate family.

Nevertheless, Ruth Suckow showed determination in sticking to her plan-to earn enough money during six months of the year to spend her winters in places of either intellectual stimulation or where she could write. She did some of her most important writing in Earlville itself. Her neighbors, when she moved into a small cottage without electricity or running water, regarded her bee-keeping as her true work. When she was inside her house busily writing they would tell visitors, 'Yes, she's at home-she isn't working today." 26

$\mathrm{H}$

ER FIRST serious short story (as contrasted to those she wrote for the college literary magazine while a student at Grinnell) was accepted and published by John T. Frederick in his magazine The Midland in February 1921. Titled "Uprooted," it has a theme common to many of Suckow's stories - the clash between the first generation of German-American farmers with the succeeding generations. She turned completely from the period of lyric poetry, from the transplanted New England culture in which she had grown up, to realism - the new school of fiction of which Frederick was a strong advocate. She first explored her German ancestry in 1917, while still living in Denver. When she returned to Iowa and began to write serious fiction, her own German-American roots became more important to her.

Ruth often accompanied her father on visits to the Suckow farm in Hancock County and became re-acquainted with her grandfather, now ninety years old. His son had run the farm for many years, but had moved into town, and a grandson was now working the farm. Grandfather Suckow refused to move to

${ }^{26}$ Ferner Nuhn, "The Orchard Apiary," The Iowan, Summer 1972, 22-54, passim. This contains an account of Ruth Suckow's years in Earlville and her bee-keeping. 


\section{The Annals of Iowa}

town, and while his wife was living, they moved into a room separate from the rest of the house. After his wife's death he stayed on in his room, and it was here that his granddaughter first visited him. He seemed to her "more like a figure in a German picture or a folk song than an actual old man. . . ." with his skull cap, silver beard and black pipe. When he finally had to move into town he lived in a little one-room building, which was called "Grandpa's House," in the back yard of his son's (Ruth's uncle's) home. He delighted in telling his grown-up granddaughter stories of his pioneer days in Iowa, and in singing German songs and telling stories to the youngest member of the household.

He was proud of his granddaughter, now beginning to achieve success as a writer, and wished he could write his own stories down. He was also an ally to her in her antipathy toward the anti-German propaganda during the war. He asked, "Didn't de Germans help to settle all dis country? Why, den, are de Germans now so bad?" The original name of his township in Hancock County-German Township-had been changed by super-patriots to Liberty Township, but the old man refused to use the new name. Ironically, Ruth Suckow's father, who became an ardent supporter of America's role in the war, thought of changing his name from Suckow to Coe, a move his daughter adamantly opposed. ${ }^{27}$

Certainly the effect of the First World War on Ruth Suckow had been a profound one. She called it an "earthquake shock" and "a blow first of all to my love of country." She wrote in "A Memoir":

A third-generation American with no emotional attachment to any older country, and no colonial heritage, I had grown up putting my national faith in the new country to which my grandparents had come with wholehearted commitment. I had taken the Melting Pot seriously; had believed that all who came and contributed to its upbuilding were equally welcome, as in the new town in which I was born. . . . ${ }^{28}$

${ }^{27}$ Suckow, "A German Grandfather," 280-281, passim.

${ }^{28}$ Suckow, "A Memoir," 245. 


\section{Ruth Suckow}

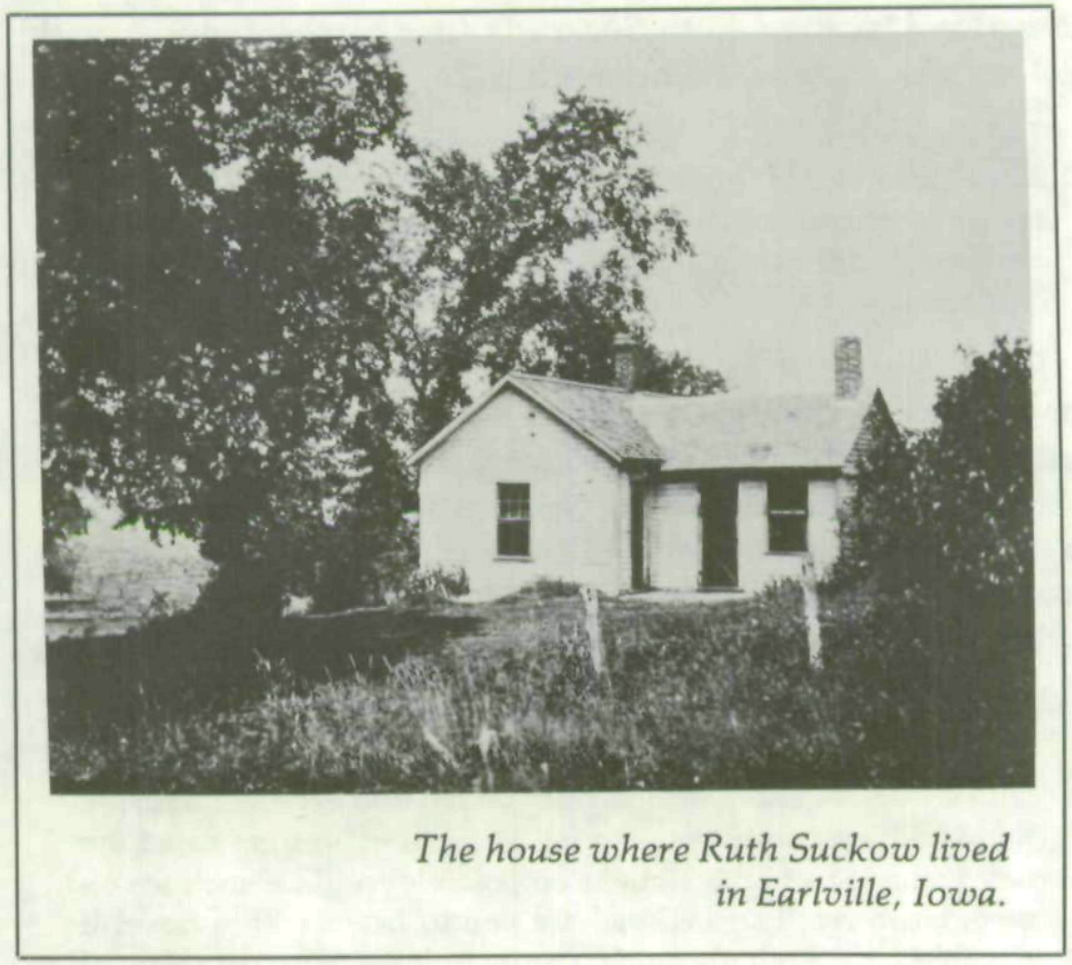

The resulting feeling of disillusionment-of being cut off, in a sense, from all she had believed in - was important in her career as a writer. Disillusionment was a theme of the group of new writers who began writing in America in the early 1920s.

In Iowa, John T. Frederick, who had founded The Midland in 1915 while still a senior at the University of Iowa, designed it to be "a journal where young writers could write realistically and honestly about their experiences." $29 \mathrm{He}$ wanted characters related to their environment, personality influenced by landscape -both qualities inherent in Ruth Suckow's fiction. In publishing "Uprooted" Frederick recognized her talent and her importance as a writer. He suggested she submit stories to H. L. Mencken's Smart Set. Mencken, who later called The Midland "probably the most influential literary periodical ever set up in

${ }^{29}$ Milton M. Reigelman, "John T. Frederick," The Palimpsest, vol. 59, no. 2 (March/April 1978): 60. 


\section{The Annals of Iowa}

America," received Ruth Suckow's first batch of stories with enthusiasm. ${ }^{30}$ He wrote her on July 26,1921 :

The three stories seem to me to be excellent stuff. I am sending. all of them to Mr. Nathan [his co-editor]. We'll undoubtedly take one of them, and probably all three. I tell you frankly they are the best stories a new author has sent in to The Smart Set in five years. ${ }^{31}$

In this first letter he asked her if she had thought of writing a novel, and told her that if she had he could help her find a publisher. By the end of that year Mencken had bought five of her short stories, and she could write to her aunt, Emma Washburn, "the writing business is looking up. Did papa tell you I had sold five short stories to The Smart Set and have prospects better than that." 32 Mencken advised her further about writing a novel and expressed his interest in her ethnicity:

As a rule, publishers are very reluctant to start off a new author with a book of short stories, but you have so excellent a title in mind and your stuff seems to me to be so interesting that I am half inclined to think it might be possible to place such a volume. However, I strongly advise you to begin with a novel if possible. . . . Knopf is doing a more or less connected series of first novels by American authors. ... I am sure your work would interest him enormously. . . . I wish I knew more about you. It is one of my pet notions that the American literature of the next generation will not come from the original Anglo-Saxon stock. What are you racially? Your name seems to indicate Slavic parentage. If you care to let me know about it, I'd like very much to hear of your ancestry and early training. Your work interests both Mr. Nathan and me vastly. As for your book, please don't consider yourself an unknown writer. By the time your manuscript is ready, you will be well enough known to approach any publisher. ${ }^{33}$

\section{Later Mencken wrote:}

As it happens, your ancestry seems to be very much like my own. My paternal grandfather came from Saxony, and there is ${ }^{30}$ Mencken, The Smart Set, July 1924, 141.

${ }^{31}$ Mencken to Ruth Suckow, July 26, 1921, Suckow Papers, UIL.

${ }^{32}$ Nuhn, "The Orchard Apiary," 54.

${ }^{33}$ Mencken to Ruth Suckow, August 9, 1921, Suckow Papers, UIL. 


\section{Ruth Suckow}

Slav blood in the family. . . . The ancestry of Dreiser is not dissimilar. The subject interests me because of my notion that the Anglo-Saxon stock in America is played out, and most of the current artistic activity is among the peoples of later immigration. ${ }^{34}$

In December 1921, Mencken wrote to Sinclair Lewis, another writer whose stories were published in The Smart Set, that he had "lately unearthed a girl in Iowa, by name Ruth Suckow, who seems to me to be superb. I send you a Smart Set with two of her stories. She follows after you [Theodore] Dreiser, and to some extent, [Sherwood] Anderson, but she is also a genuine original." ${ }^{35}$ Two months later, in February 1922, he wrote Lewis again: "I am sending your message to Miss Suckow. It should please her vastly. At last accounts she was still at work on her novel. I told Knopf about her when she first bobbed up, and I believe he has bespoken her novel. But let Harcourt lay on." ${ }^{36}$

Before her first novel was finished Mencken had found her a publisher, his friend Alfred A. Knopf. He wrote to Franklin Spier of the Knopf company on August 9, 1921:

A young woman named Ruth Suckow at Earlville, Iowa has sent in to us a number of very remarkable short stories. She tells me that she is at work on a novel. I suggest that it would be a good idea to send her a friendly note, saying that I have told you about her and that you will be glad to read her manuscript when it is finished. I am convinced that she will do excellent work. ${ }^{37}$

The book of short stories which she had suggested to Mencken was undoubtedly Iowa Interiors which was not published until after her first two novels. The novel on which she was at work was Country People. Her output during these years is prolific. Short stories continued to appear in The Midland and The Smart Set. A short novel, "The Best of the Lot" was published in The Smart Set in November 1922, and the story about Grinnell, "A Part of the Institution," in October 1923. When her short story, "The Renters," appeared in the 1923 issue of The

${ }^{34}$ Mencken to Ruth Suckow, August 16, 1921, Suckow Papers, UIL.

${ }^{35}$ Forbes, ed., Letters of H. L. Mencken, 231.

${ }^{36}$ Ibid., 233.

${ }^{37}$ Ibid., 227. 


\section{The Annals of Iowa}

Century Magazine, Mencken wrote to its editor, Carl Van Doren, "You owe me something for stealing Ruth Suckow. But do not gloat! I have laid up for the first number of The American Mercury the best short story she ever wrote." ${ }^{\prime 38}$ This was "Four Generations" which was published in the first number of Mencken and Nathan's new magazine, The American Mercury, in January 1924.

As its title implies, "Four Generations" is about a family reunion on the family farm of the descendants of the old German farmer who had settled the land. His son had moved to town and prospered in business, his granddaughter had married a New Englander and become a snobbish pseudo-easterner. It is her little girl, the great-granddaughter, who shows affinity for her great-grandfather, and sits on his lap to listen to his German songs. The theme clearly reflects Suckow's interest in her own grandfather and the changes a family goes through as younger generations leave the farm to seek their fortunes elsewhere.

In 1923 the novel Mencken had been encouraging her to write was finally ready. It was accepted for publication by Knopf in May 1923, but was first published in four installments in The Century Magazine (January through April issues, 1924). Country People is a remarkable novel, written after Suckow first returned to Iowa in 1921. The novel is a chronicle of a German family on the rich farmland of Hancock County, Iowa. It covers the period when her fictional family, the Kaetterhenrys, came to America between 1850 and 1920. The changes in the generations from the hard-working pioneers up to the then present generation, from horse and buggy to the Model-T Ford, are told with careful attention to detail, Ruth Suckow's forte. When the novel appeared in bookstores and libraries in Iowa it sent shock waves through the countryside, just as Sinclair Lewis's Main Street had stirred up dust in his native state of Minnesota. Iowa readers objected to the stark realism of the novel, as it depicted the drab monotony in the lives of hardworking farmers, their wives and children. In her central figure, August Kaetterhenry, she portrayed the diligent, materialistic German-American farmer whose ultimate goal was to save up enough money to move to town.

${ }^{38}$ Ibid., 258. 


\section{Ruth Suckow}

Country People also exposed the prejudice against the German farmers during the First World War:

The feeling in the neighborhood against the German farmers had grown to a degree that would have seemed incredible at the beginning of the war. August "got off easy" compared with some of them. He had two boys in the service, he could keep his mouth shut, he bought Liberty bonds. . . . Some of the other German farmers came up before the board because of things they had said, or were reported to have said. Old Haas's corn crib was burned. But nothing worse happened to August than being yelled at on the street and finding painted in crude red leters on his barn: "Old Dutch Kaetterhenry. Hun. Bosh. Look Out." ${ }^{\prime \prime 9}$

When her third novel, The Bonney Family, came out in 1928, again published by Knopf, Helen Cowles LeCron, editor of the Des Moines Register's Sunday book page, summed up the ambivalent attitude of many lowans toward Ruth Suckow:

'More drab realism, I suppose,' some are sure to be thinking bitterly. Just the kind of book that makes eastern critics think Iowa is a dreary waste.' If you only knew it, dear readers, Ruth Suckow in the books she has already written (and in future ones) is paying lowa a greater compliment than any of our other writers has done so far..$^{40}$

In answer to an article by Frank Luther Mott, "Do Iowa Writers Hurt Iowa," also on a Des Moines Register book page, Suckow wrote a parody, "An Iowa Farm Story Revised," which she declared was to "remodel the farm story on which she was working and to offer it in its new version to our readers as a sop." This witty parody is a shrewd comment on the social scene of the middle 1920s. Her farmer was one Stephen A. Wisecracker who lived "within easy driving distance by highpowered motor from the beautiful little growing city of Doodad in the heart of the richest farming country in Corn Township," which is in Tassel County "in the state of Iowa in the ... richest farming country in the great Middlewest (that is every bit as

${ }^{39}$ Ruth Suckow, Country People (New York: Alfred A. Knopf, 1924), 107108.

${ }^{40}$ Helen Cowles LeCron, "Iowa Writers," Des Moines Sunday Register, undated clipping, Ruth Suckow Memorial Library, Earlville, Iowa. 
good as the East!)." The daughter of the family, Violette Virginia Mary, was chosen "Miss Rural Route 3, Miss Doodad City, Miss Corn Township, Miss Tassel County" and finally "Miss Iowa." Mrs. Wisecracker belonged to the Higher Culture group of the Doodad Woman's Club, and the son Frank promised to be a sculptor-he has already made a bust of Calvin Coolidge who "is sojourning in the Black Hills within easy driving distance of Tassel County." ${ }^{41}$

This is satire in the best tradition of Sinclair Lewis. In her serious fiction she studiously "kept out of the stories . . . and let the characters live," she wrote in the preface to Carry-Over, a reprint of Country People and other fiction (1926). In her essays "Iowa," and "My German Grandfather," published in 1926 and 1927 after she had gone to New York, her criticism was incisive. Although her articles were not strident in the de-bunking Mencken style, still she voiced her opinions candidly and vigorously. She spent the winters of 1925 and 1926 in New York, despite the advice of her mentor, Mencken, who wrote her in 1921:

I don't think living in New York would help you in the slightest. As a matter of fact, very few writers are able to work there at all; I can recall but one or two. All the best writing of the time relates itself to the Middle West. Greenwich Village is simply a collection of frauds. I see practically everything it produces. It is trivial and even infantile. Of course, it would amuse you to visit the place, but please don't think of living there. ${ }^{42}$

In January 1926 Ruth wrote a friend, describing New York as she found it:

New York is varied and infinitely amusing, most absurdly and delightfully theatrical, a holy show all the time but such a big bluff. . . . The literary gang here, as a gang, is just as bad and hopeless in its way as the Iowa Press and Authors Club. Except for the sake of change and variety, I doubt if there's much advantage in leaving the Middle West. An insidious taint and false stagey veneer is apt to get into things here. I shouldn't want to stay and get involved in it..$^{43}$

${ }^{41}$ Ruth Suckow, "An Iowa Farm Story Revised," Des Moines Sunday Register, undated clipping, Suckow Papers, UIL.

${ }^{42}$ Mencken to Ruth Suckow, August 16, 1921.

${ }^{43}$ Ruth Suckow to J. Hyatt Downing, January 28, 1926, Booklet (Iowa City: Ronald D.: Knibbs, n.d.), UIL. 


\section{Ruth Suckow}

Nevertheless, by the end of the summer of 1926 , she sold her apiary and moved to New York. A glimpse of her departure is given by Harlan Miller, originator of the famous column, "Over the Coffee," in the Des Moines Register. With the headline, "Ruth Deserts Apiary for Lil' Old New York" he wrote:

Miss Ruth Suckow, the quiet, observant young woman who, in the eyes of the literati, is Iowa's foremost candidate for immortality, has sold her bee farm, and is on her way to New York to look for a job while she writes her next novel. . . . [She] hugged a portfolio plump with manuscripts, the embryo of one story and novel. In the other hand, she held an umbrella, emblem of realism. ${ }^{44}$

Miller found her "calm, witty, caustic" in informal gatherings, and reported that she spoke of her apiary as being in the "bee loud glades of Earlville." As a writer she was a "remote, implacable observer who appears to recede behind the pages of 'Country People' and to a lesser degree, the pages of the 'Odyssey.'"

In New York she looked for a job reading manuscripts for publishers. Although her books had been critical successes, they were not earning her much money. "People have the idea that if the critics will only speak well of you, you are made," she said in one of her rare newspaper interviews. "It isn't nearly so simple." She found editors "fearful of experimenting with the new and untried.... and send writers the critics have acclaimed but which the public has had hardly a chance to know, nice, warm, encouraging letters of rejection." 45

The collection of her early short stories, most of which had appeared in The Midland or The American Mercury was published by Knopf in 1926 under the title Iowa Interiors. In a review of this book, Mencken could not contain his enthusiasm for Suckow: "She is unquestionably the most remarkable woman now writing short stories in the Republic; all the rest, put beside hers seem hollow and transparent." ${ }^{46}$ Her books also received notice from critics for leading New York newspapers, and her short stories continued to be published in The

${ }^{44}$ Harlan Miller, "Over the Coffee," Des Moines Register, December 1926. ${ }^{45}$ Starkey, The Boston Evening Transcript.

${ }^{46}$ Mencken, "The Library," The American Mercury, vol. 9, no. 35 (November 1926), 382. 
American Mercury as well as in Harper's Monthly Magazine. Mencken had encouraged her to try the women's magazines earlier because they paid better, and by 1929 she was being published in Good Housekeeping, which also serialized The Kramer Girls in 1930 (published by Knopf in 1931), her first financial success.

Her last autobiographical novel of the 1920s was The Bonney Family. In Country People she had written of just such an Iowa farm as her grandfather and father knew; in The Odyssey of a Nice Girl she had used many of her own experiences in her own personal odyssey (although her heroine settled for a mediocre marriage rather than pursuing a career); in The Bonney Family she wrote of a minister's family, with many of the settings and characters reflecting Manchester and Grinnell, especially Grinnell College. She had brought together all of the experiences and observations of her own life. Of the novels, Country People has endured, having gone through three printings. In 1943 Sinclair Lewis selected Country People for the anthology, The Three Readers, which he, Clifton Fadiman and Carl Van Doren put together. In defending his choice he wrote:

Miss Suckow tramps the road at hot noon. . . . Born in 1892 in Grant Wood's Iowa, where there is nothing to be seen but corn stalks and college towers and secretaries of agriculture, she has stayed there except for aberrations into heathen California and Greenwich Village, and that is very fortunate for Iowa, which she has re-created in such genuinely native novels as The Folks, and the Bonney Family, and the recently published New Hope. ${ }^{47}$

All four of her books of the 1920s were published in England by Jonathan Cape, Ltd., under the American titles except for Iowa Interiors which was changed to People and Houses. Her short stories of this period have been widely anthologized and are still being read by students in high school or college literature courses. Her most popular short story has been "A Start in Life." Ferner Nuhn, in his essay "An Orchard Apiary," stated that Ruth Suckow got her own "start in life" in Earlville.

In going to New York's Greenwich Village she followed in the

${ }^{47}$ Sinclair Lewis, Clifton Fadiman, and Carl Van Doren, eds., The Three Readers (New York: The Press of the Readers Club, 1943), 176. 


\section{Ruth Suckow}

footsteps of many other young Iowans of the post-war era, and in an essay titled "Iowa" she explained why. The home town was "dead," she declared, and a young man who went back home after college was regarded as ambitionless. By the same token, "flocks of talented girls graduated every year from the colleges must go East, if they were to live up to the flowery expectations held for them." Forcing themselves into "rootless exile" these young people were not entirely to blame, because they had been taught in Iowa that a gulf existed between the "experience of life and the experience of books." Culture, art and beauty were "fixed in certain places," and so that when living at home "all our bright young people grew up with the curious sense of exile." 48

I $_{\mathrm{N}}$ "IowA" Suckow issued her manifesto, already evident in Country People and her short stories, that the bedrock of Iowa culture was not to be found in the conventional upper levels of society but in the hard-working, stubborn, individualistic farm people. Although the farmers were considered illiterate, uncouth, raw by conventional standards, Ruth Suckow elevated them to the highest position, over the descendants of the New England settlers, over the leaders of liberal arts colleges whose Puritan idealism had been watered down by financial greed, over the materialistic middle class with its houses, automobiles, and radios, and even over the retired farmers who had moved to town or migrated to California. According to Suckow, none of these classes yielded anything but a spurious culture; it was among the farmers who still worked the soil that a true native culture would be found.

Without fear, she did indeed "tramp the road at high noon," and in doing so set the pace for a new group of Iowa writers. "A terrific rattle of typewriters has broken out," she wrote, adding:

Newspapers are beginning to carry book columns of their own.

People dare to send their unsubstantiated opinions to the liberal and lively book page of the Des Moines Register. The group at

${ }^{48}$ Ruth Suckow, "Iowa," The American Mercury, vol. 9, no. 33 (September 1926), 41. 


\section{The Annals of Iowa}

the state university has at last been accepted as culturally respectable in spite of its native origin.

This was in contrast to an earlier period when Herbert Quick had been told that Iowa was not literary material. She lamented that Hamlin Garland "fell by the wayside," and felt that Quick "kept faith with his material and in the end his achievement is to be respected." Literature emanating from Iowa in the 1920s was no longer in the hands of a "caste" but everybody was "snatching at it, from farmer boys, dentists, telegraph editors in small towns" to the "bands of ladies who meet to discuss the literary markets (wearing smocks in one instance as a badge of aesthetic dignity) and who yearn to desert their husbands for a year at Columbia." This in 1926! In this as in many other ways, Ruth Suckow was a woman ahead of her time, who discovered in Iowa men and women ahead of their time.

Greenwich Village in New York was of course vastly different from the rural Iowa town of Earlville, and it changed her. No longer was she going up and down the dusty main street of the little town to her apiary. Her Greenwich Village life is highlighted in the interview for the Boston Transcript:

She lives two or three flights up in one of those old-fashioned, rose-red brick apartment houses, and she was out on the landing waiting for me. She is in her thirties, of medium build and height, her hair is blonde and bobbed and banged, and that day she was all in geranium red, ... her voice is low and cultivated, her laugh also low and very musical and not infrequent, ... she has one mobile eyebrow, her right, which has an engaging way of lifting when she becomes animated or amused.49

Her apartment was furnished in the style of the 1920s-wicker chairs, bridge lamp, rows of bookshelves. She offered her interviewer a Turkish cigarette and they talked of Ruth Suckow's current literary preferences, which included the English writers Dorothy Richardson and Katherine Mansfield, and the Norwegian novelist, Sigrid Undset (who later became a close friend and visited in lowa when Ruth Suckow and Ferner Nuhn were living in Cedar Falls). Among the poets she admired were the Americans Robert Frost, Emily Dickinson, and Edna St. Vincent Millay.

${ }^{49}$ Starkey, The Boston Evening Transcript. 
In this interview we also catch a glimpse of Ferner Nuhn, the young man from lowa, whom she married in 1929:

Within the apartment, hastening into hat, coat and muffler, was her husband, also personable and much taller. . . . He stopped hardly longer than to say hello, and to ask if he needed rubbers, for Ferner Nuhn is a writer, too, and was just on the point of plunging into the foggy world outside in pursuit of an editor.

He had first come to New York to attend Columbia University in the late 1920s, but turned to writing, and sold three short stories to Mencken for The American Mercury, which were published in 1927 and 1928. When the first story, "Ten," appeared in the Mercury, "The American Mercury Authors" department described Nuhn as "a young Iowan. His mind was set on a professorship in English, but he gave up the quest in disgust, and is now writing instead." ${ }^{50}$ The story has recently been reprinted in Three Stories Plus Two Verses, privately published by Nuhn in Claremont, California. His stories, like his wife's, have an Iowa locale.

Ruth Suckow's final short story in The American Mercury was "Mrs. Kemper" in the April 1929 issue. Altogether Mencken and Nathan had published eighteen short stories and the two essays, "Iowa," and "A German Grandfather" in The Smart Set and the Mercury. In H. L. Mencken, Literary Critic, William H. Nolte states that Mencken's interest in fiction began to wane by 1925 , and the Mercury did not publish nearly as many short stories as had The Smart Set. The 1920 s was a unique decade in American publishing, Nolte points out: "with the possible exception of the eighteen-fifties, no ten-year period in American history has been so productive of literary art as the decade following World War I and terminating with the stock market crash in October, 1929." 51

At the end of the twenties, John T. Frederick, who had given Ruth Suckow her first real encouragement and who was the link between her and Mencken, wrote in an article "The Younger

so "American Mercury Authors," The American Mercury, vol. 12, no. 48 (December 1927), 510.

${ }^{51}$ William H. Nolte, H. L. Mencken, Literary Critic (Middletown, Connecticut: Wesleyan University Press, 1964), 227. 


\section{The Annals of Iowa}

School" which appeared in The Palimpsest in February, 1930: "Undoubtedly 'Towa Literature' is identified most generally in the minds of American critics and readers with Ruth Suckow." Of Country People he wrote: "It is a compact epic of the Iowa soil, conveying a very strong sense of the movement of agricultural life in lowa in the last three generations." Against the charge of drabness in her fiction, which Iowa readers had made, he declared that Ruth Suckow had an "intensely poetic feeling for the Iowa landscape. This is never absent from her work though it is never allowed to intrude or to overbalance the effects she desires." 52

Of her own work, she said in an interview for the New York World:

What I wrote about was not the soil but country people. I never belonged to any school and I don't like method as such. . . . I have been astounded by the interpretations that have been read into my work. I have never, for example, been a rebel or a satirist, in the Sinclair Lewis sense. ${ }^{53}$

As for those people who thought they recognized themselves in her fiction, she said in the Boston Transcript interview:

No, I don't draw any characters direct from life. It simply wouldn't be much fun. Of course all of them derive from life. Traits of people you meet, people you remember, merge themselves more or less unconsciously with the portrait on which you're engaged..$^{54}$

After her highly successful output of the 1920s, Ruth Suckow was recognized by her fellow Iowans in 1934, the year her novel, The Folks, was published by Knopf, when she was named lowa's Woman of the Year in a Des Moines Register poll. Henry Wallace was Iowa's Man of the Year, and President Franklin D. Roosevelt and Secretary of Labor Frances Perkins were named the Nation's Man and Woman of the Year. In 1935 Suckow received the Iowa Library Association's Award for

\footnotetext{
${ }^{52}$ John T. Frederick, "The Younger School," The Palimpsest, February 1930, 82-83.

${ }^{53}$ Harry Salpeter, "Ruth Suckow, Novelist," New York World, December 13, 1929.

${ }^{54}$ Starkey, The Boston Evening Transcript.
} 


\section{Ruth Suckow}

Literary Achievement and in 1931 Grinnell College awarded her an honorary Master of Arts degree.

A more recent distinction has come with a quotation from her essay, "Iowa," in Joseph F. Wall's recent history, Iowa.

... Almost the only claim of Iowa among these United States (aside from a little pride in the matter of corn and hogs) has been for the place of the lowest. But yielding itself thus, not only submissively but with ardor to the charge of provincialism, it lost colonialism, by far the more insidious disease of the two,

Wall comments, "With poetic license Suckow somewhat overstated her case, but there is considerable validity in all halftruths, and her description of Iowa is more than half true, not only for them but for fifty years later." 55

The key word in the passage Wall selected for quotation is "colonial," which Ruth Suckow struggled against in her own life, and which led her to write many highly original and perceptive short stories and novels. Certainly her growing up as a minister's daughter gave her the experience of living in and knowing many Iowa small towns, but much credit must also be given to her German ancestry, especially her Grandfather Suckow, for awakening her understanding of the German element in Iowa's culture.

${ }^{55}$ Joseph Frazier Wall, Iowa (New York: W. W. Norton and Co., Inc., 1978), xvii. 
Copyright of Annals of Iowa is the property of State of Iowa, by \& through the State Historical Society of Iowa and its content may not be copied or emailed to multiple sites or posted to a listserv without the copyright holder's express written permission. However, users may print, download, or email articles for individual use. 